\title{
Unusual venous anomaly leading to malposition of dialysis catheter into the accessory hemiazygos vein
}

\author{
Monique Oye (ㄷ, ${ }^{1}$ Natalie Torrente, ${ }^{1}$ Brittany Lyons, ${ }^{2}$ Win Aung ${ }^{2}$
}

${ }^{1}$ Internal Medicine, University of Florida Health at Jacksonville, Jacksonville, Florida, USA ${ }^{2}$ Internal Medicine, University of Florida College of MedicineJacksonville, Jacksonville, Florida, USA

\section{Correspondence to} Dr Monique Oye; monique.oye@jax.ufl.edu

Accepted 8 November 2020

Check for updates

(c) BMJ Publishing Group Limited 2020. No commercial re-use. See rights and permissions. Published by BMJ.

To cite: Oye M, Torrente N, Lyons $\mathrm{B}$, et al. BMJ Case Rep 2020;13:e238264. doi:10.1136/bcr-2020238264

\section{DESCRIPTION}

A 47-year-old African American woman with a history of chronic kidney disease stage IV presented with anaemia and acute kidney injury secondary to bleeding uterine fibroids. Haemoglobin on admission was $5.1 \mathrm{~g} / \mathrm{dL}$ and creatinine $4.52 \mathrm{mg} / \mathrm{dL}$. Her renal indices continued to worsen during admission; she became oliguric with estimated glomerular filtration rate declining to $\left(8 \mathrm{~mL} / \mathrm{min} / 1.73 \mathrm{~m}^{2}\right)$. Decision was made to initiate haemodialysis. A 16 $\mathrm{cm}$ temporary haemodialysis catheter was placed via the left internal jugular vein for venous access. Non-pulsatile dark blood was aspirated, and wire placement was confirmed by real-time ultrasound prior to proceeding with dilation. The haemodialysis catheter was placed without difficulty using the Seldinger technique. After line placement, chest radiograph was obtained to confirm the position. Chest X-ray revealed that the line was positioned on the left side of the mediastinum, following an abnormal course inferiorly, not crossing midline (figure 1A). CT chest was obtained to further characterise placement prior to initiating haemodialysis. CT revealed an enlarged hemiazygos system, with collateral vessels identified within the mediastinum (figure 2A,B). The dialysis catheter was visualised on the left side, with the tip projecting into the accessory hemiazygos vein. Under fluoroscopy guidance (figure 1B), the catheter was exchanged, and the tip placed into the cavoatrial junction so it could be accessed for haemodialysis.

Malposition of central venous catheters into the accessory hemiazygos vein is a rare complication. Knowledge of normal and abnormal venous anatomy is needed when interpreting line position, so complications can quickly be recognised when they arise. Typically, the accessory hemiazygos vein drains into the left brachiocephalic via anastomosis with the superior intercostal vein. Our patient had
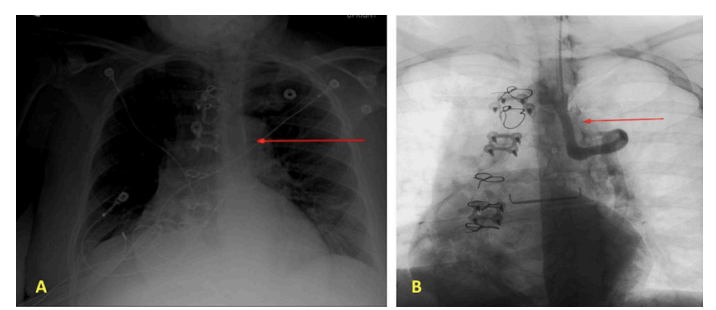

Figure 1 (A) Chest radiograph depicting left internal jugular central venous catheter following an abnormal course inferiorly, not crossing midline. (B) Superior vena cava venogram via temporary haemodialysis catheter showing the tip of haemodialysis catheter in a large left accessory hemiazygos vein (red arrow). a venous anomaly consisting of a large hemiazygos system which was dominant. This anomaly caused the catheter to flow from the left internal jugular vein, into the superior intercostal vein and then directly into her accessory hemiazygos vein, instead of into the desired position at the cavoatrial junction (figure $2 \mathrm{C}-\mathrm{F}$ ).

Potential clinical consequences of catheter placement into the azygos vein system include pleural effusion, pulmonary oedema, chest pain, back pain and cardiac tamponade. ${ }^{1}$ Patients can also experience venous perforation, thrombosis and occlusion leading to increased morbidity and mortality if not recognised in a timely manner. ${ }^{2}$ Management typically includes repositioning the catheter under radiological guidance.

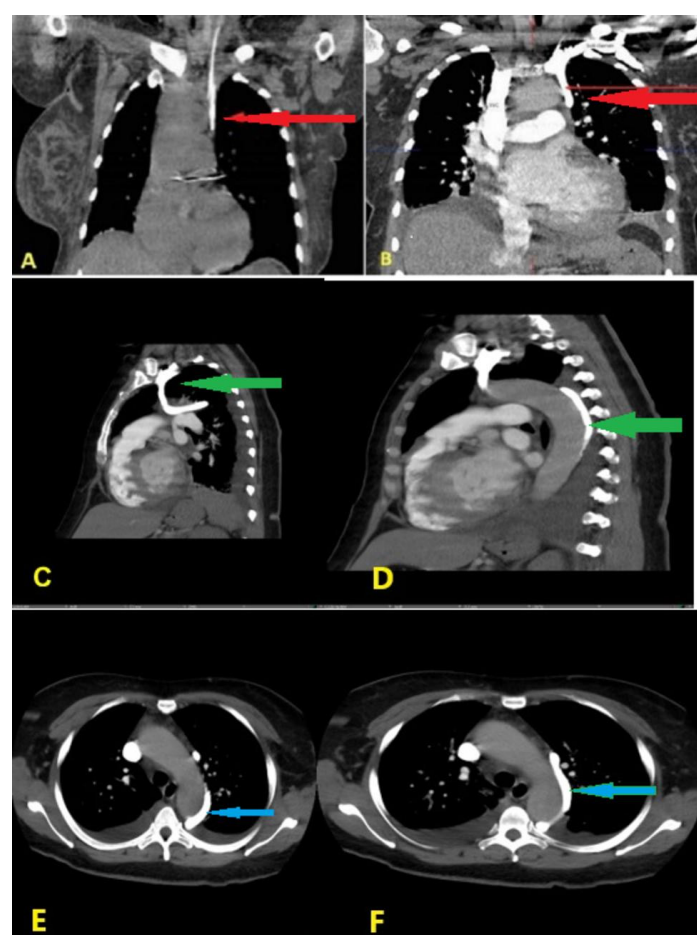

Figure 2 (A) CT chest with left-sided central venous catheter identified with the tip projecting in the accessory hemiazygos vein just below the aortic arch (red arrow).

(B) CT angiography showing enlarged azygos system, with collateral vessels identified within the mediastinum (red arrow). (C, D) Sagittal view depicting the path of the central venous catheter by anastomosis of the superior intercostal vein into the dominant left accessory hemiazygos vein. $(E, F)$ Axial images depicting the path of the central venous catheter through the superior intercostal vein into the accessory hemiazygos vein. 
Our top differential diagnoses for left-sided catheter location included carotid artery cannulation and persistent left-sided superior vena cava. To rule out artery cannulation, a venous blood gas was performed which showed the blood was venous in nature. CT chest was able to further reveal the exact location of the catheter. The vein was not draining directly into the right atrium and we were able to rule out persistent left-sided superior

\section{Learning points}

The preferred position for the central venous catheter tip is the junction of the superior vena cava and right atrium.

- Although central venous catheter placement is a relatively safe procedure, patients with abnormal venous anatomy are predisposed to line malposition during insertion. Malposition of central catheters into the azygos vein system is a rare but potentially dangerous complication.

- Contrast-enhanced CT, MRI studies and venography are all suitable imaging options to further determine central venous catheter location. Management typically includes repositioning the catheter under radiological guidance. vena cava. Other potential differentials include extravascular placement, for example, into the mediastinum or pleural space. Congenital anomalies such as partial anomalous pulmonary venous return can also reveal a left-sided catheter not crossing midline. Fortunately, in our patient case, the line was adjusted promptly, and she did not experience any adverse outcomes.

Contributors All authors provided direct patient care to patient, workup/diagnosis of patients condition, drafting of the case report, literature review and editing. All authors approved the final version of the manuscript.

Funding The authors have not declared a specific grant for this research from any funding agency in the public, commercial or not-for-profit sectors.

Competing interests None declared.

Patient consent for publication Obtained.

Provenance and peer review Not commissioned; externally peer reviewed.

\section{ORCID iD}

Monique Oye http://orcid.org/0000-0002-0725-2716

\section{REFERENCES}

1 Wang L, Liu Z-S, Wang C-A. Malposition of central venous catheter. Chin Med J 2016;129:227-34

2 Moon E, Jeong H, Chung J, et al. Central venous catheter malposition in the azygos vein and difficult endotracheal intubation in severe ankylosing spondylitis: a case report. Int J Clin Exp Med 2015;8:21755-9.

Copyright 2020 BMJ Publishing Group. All rights reserved. For permission to reuse any of this content visit

https://www.bmj.com/company/products-services/rights-and-licensing/permissions/

BMJ Case Report Fellows may re-use this article for personal use and teaching without any further permission.

Become a Fellow of BMJ Case Reports today and you can:

- Submit as many cases as you like

- Enjoy fast sympathetic peer review and rapid publication of accepted articles

- Access all the published articles

Re-use any of the published material for personal use and teaching without further permission

Customer Service

If you have any further queries about your subscription, please contact our customer services team on +44 (0) 2071111105 or via email at support@bmj.com.

Visit casereports.bmj.com for more articles like this and to become a Fellow 